\title{
Portugal no Brasil: a escrita dos irmãos desavindos
}

Élio Serpa

Universidade Federal de Santa Catarina ${ }^{1}$

RESUMO

$\mathrm{O}$ artigo aborda as polêmicas travadas pelos intelectuais portugueses e brasileiros nas revistas de História, Seara Nova, Nação Portuguesa e Lusitânia . Estas polêmicas referem-se à literatura e à língua e revelam que esses intelectuais form forjados no interior de uma cultura política nacionalista, eurocêntrica e colonialista.

Palavras-Chave: Nacionalismo; Cultura; Política; Raça.
ABSTRACT

This article is about the controversies between both Portuguese an Brazilian intellectuals in the reviews de História, Seara Nova, Lusitânia e Nação Portuguesa. These controversies refer to the literature, language and show that such intellectuals were brought up into a culture consisting of a political, nationalistic, racial, euro-centric and colonialist society.

Keywords: Nacionalism, Political Culture, Race.

PortugAL NO BRASIL : MÃE-PÁTRIA E POVO MOÇO

Portugal e o Brasil na Primeira República envolveram-se em situações, por vezes, embaraçosas em termos de relações diplo máticas, mas é no mundo da palavra escrita, tendo como veículo a literatura, que os dissensos se explicitaram a partir do desejo de partilhar a constituição estética do mundo sensível que, à época, era expresso por parte de alguns intelectuais portugueses e brasileiros, pelo nacionalismo, na forma de existência de interesses comuns entre Brasil e Portugal. Os intelectuais portugueses produziam representações do Brasil em revistas, jornais, livros, cinema e fotografias. Assim a Revista de Histónia ${ }^{2}$ iniciou sua circulação em 1912 e colocou-se como uma publicação da Sociedade Nacional de História Portuguesa ${ }^{3}$. A revista Águia publicada na cidade do Porto iniciou a sua circulação em 1910. Nas palavras de Teixeira Paschoaes, sur- 
giu como órgão da Renascença Portuguesa. Veio para dar sentido às energias intelectuais, para torná-las fecundas e realizar o ideal de criar um novo Portugal, ressuscitar a Pátria Portuguesa, arrancá-la do túmulo. A revista Nação Portuguesa considerava-se uma revista de Filosofia Política. Iniciou sua circulação em 1914, em Lisboa e defendia para Portugal uma monarquia orgânica, tradicionalista e anti-parlamentar ${ }^{5}$. A revista Lusitâ nia surgiu em 1924; qualificou-se como um órgão independente e como movimento de recriação do espírito nacional. Postulou comunicar-se com o espírito do mundo, mas por sentimentos e inteligência elegeu o Brasil e a Espanha como seus interlocutores privilegiados ${ }^{6}$ A revista Seara Nova começou a circular em 1921; definiu-se como representante do esforço de alguns intelectuais, fora dos partidos políticos, mas não da vida política e se propôs contribuir para as reformas necessárias à vida nacional'.

Portugal, desde o século XIX, enfrentava problemas internos e externos. Aos olhos das nações européias que discutiam quem poderia ser considerada nação, tinha dificuldade em alçar-se enquanto tal pois, segundo Hobsbawm, "o Dictionair e Politique de Garnier-Pagés de 1843 considerava ridículo que a Bélgica e Portugal fossem nações independentes, porque eram manifestadamente demasiado pequenas ${ }^{\prime \prime} \mathrm{e}$, na primeira república, Portugal debatia-se em torno de sua afirmação enquanto nação forte e imperialista, vivenciava embates entre monarquistas e republicanos e tinha seus interesses colonialistas ameaçados. No Brasil, desde o século XIX, alguns intelectuais sentiam-se responsáveis pela difícil tarefa de criação da nação e, para tanto, envolviam-se em discussões em torno da constituição da nacionalidade. Neste sentido, a escrita literária assumia uma dimensão importantíssima no estabelecimento da diferença, da busca da originalidade e do desejo de autonomia que se contrapunha aos interesses da chamada "mãe-pátria".

Pode-se dizer que nessas revistas os intelectuais portugueses, formados na cultura política nacionalista, objetivavam internamente padronizar tradições, criar projetos educacionais unificadores, propor formas unificadas de ler o passado e criar valores e tradições, como forma de constituir cidadãos de um país ternitorial e lingüisticamente definidos. Estes intelectuais investiram na possibilidade de intervir na política cultural encetada pelo Estado para que esta pudesse atingir a elite e o cidadão comum, sendo que tal política tinha sempre uma dimensão nacional e homogeneizadora. Havia com esta prática de produção de revistas uma política de aproximação entre a população e o Estado, de tal forma que não fosse perceptível a separação. Estado, nação e sociedade deveriam ser 
convergentes. A partir do pressuposto que todos deveriam convergir para um único sentido idealizava-se o bom cidadão e a pátria grandiosa por seus feitos no passado serviria como exemplo no presente. Externamente as revistas funcionavam como propagadoras da cultura intelectual portuguesa, como veículos de difusão das idéias fixando uma memória coletiva de sua tradição e mostrando aos demais países europeus seu pendor imperialista mediante discurso de ser "criador de nacionalidades". Com isso, marcavam presença no contexto das políticas colonialistas e, acima de tudo, dialogavam com o Brasil na medida em que este era o emblema da positividade da sua política colonialista e serviria como exemplo para as colônias portuguesas, em África.

Fidelino de Figueiredo, intelectual português responsável pela publicação da revista História, publicou, em 1925, um artigo intitulado "Um século de relações luso-brasileiras". Este artigo foi escrito para compor um livro em comemoração ao centenário do jornal Diário de Pernambu co. $\mathrm{O}$ autor registrou entre tantas coisas que "outrossim, os portugueses, se têm o direito de advogar o prestígio da velha metrópole, de promover a fruição de todas as vantagens legítimas da língua comum, alargando em Santa Cruz o conhecimento da cultura nacional e dos seus deveres, têm de saber que lhes corre o dever de atenuar a uma medida razoável e equilibrada a proclamação da parte gloriosa, que lhes cabe no erguer da pátria brasileira e que ninguém disputa, e de reconhecer o muito que o povo irmão fez num século de independência”". Fidelino iniciou a escrita de seu artigo a partir de um outro texto de Renato Almeida, escritor brasileiro que se posicionou contrário à idéia de ser o Brasil um desdobramento português na América; defendeu a idéia de que a condição de americanos libertou os brasileiros da dependência européia e que o seu destino não seria dar continuidade à obra portuguesa, mas fazer algo livre e próprio, com marcas das influências e heranças recebidas, sem sujeição e sem domínio; afirmou não querer sujeição política nem unidade literária com Portugal, pois não acreditava serem forças capazes de orientar o Brasil; sua finalidade se traçava em outros termos e para outros destinos. Ponderou que não havia como falar em raça comum, quando o caldeamento étnico do Brasil produziu tipos tão diversos dos portugueses e a transformação da língua, no Brasil, acentuava cada vez mais a separação ${ }^{10}$.

Esta argumentação possibilita perceber-se a dimensão da problemática existente entre a chamada "mãe -pátria" e o "povo moço". Se a questão crucial e emergencial do Brasil era constituir-se enquanto nação, esta condição, para Fidelino de Figueiredo, já havia sido dada pelos portugue- 
ses por meio da língua e da contribuição portuguesa para a formação e dilatação das fronteiras, bem como para a criação de manifestações literárias. Aí reside toda uma problemática. $\mathrm{O}$ desejo de Portugal estar no Brasil, não diretamente na administração política, mas nas coisas do espírito ou naquilo que é chamado de "Brasil Mental", tendo como referencial o peso da tradição que lembrava em muito o pacto colonial. Era isto que alguns intelectuais brasileiros rejeitavam, enquanto arautos da construção da nacionalidade. Queriam, então, alguns intelectuais portugueses, mediante suas escritas, alimentar uma nova dependência? Por que esses intelectuais portugueses dialogavam nesse nível com alguns intelectuais brasileiros e vice-versa?Que escrita da história resultou desta relação?

Tais considerações apontam para a significação da prática da escrita no sentido de mobilizar homens e mulheres, de construir e desconstruir efeitos de verdades, exercendo um papel político. Sendo a escrita, desde o seu surgimento, monopólio de poucos, serviu para legitimar poderes, conferir primazias ou privilégios, definir posses, projetar sonhos, desclassificar saberes e formas de expressão, legitimar e divulgar a interdição, mas também a liberdade. A escrita, como diz Rancière, torna-se uma prática política à medida em que o "ato de escrever é uma maneira de ocupar o sensível e de dar sentido a essa ocupação. Seu gesto pertence à constituição estética da comunidade e se presta, acima de tudo, para alegorizar essa constituição"11. Essa constituição estética da comunidade torna-se visível pela existência de artefatos político/culturais, tais como: a necessidade de uma constituição que definisse política e administrativamente a nação, com arraigada defesa da soberania, estabelecimento de um regime de governo do povo, podendo ser monárquico mas, preferencialmente, republicano; necessidade de afirmação da democracia por meio da participação política do povo, levando à invenção da escolha dos representantes pelo voto; invenção de bandeiras, hinos, moedas, selos e representações forjadas de um cidadão típico onde as categorias trabalho, raça, patriotismo e língua nacional passam a ser critérios fundamentais; arrolamento de características próprias para cada nação, definição de fronteiras territoriais e culturais imaginárias, estudo e aprimoramento de questões referentes à língua matricial; investimento na produção de saberes construtores e/ou afirmadores de características pertinentes à nacionalidade ideal e ao cidadão desejado.

O que pretendo mostrar são as lutas no campo intelectual entre portugueses e brasileiros num momento muito específico para ambos: parte da intelectualidade portuguesa debatia-se em torno da afirmação e ex- 
pansão de sua tradição intelectual no contexto da política cultural do nacionalismo e colonialismo, e parte da intelectualidade brasileira, em torno de ideais nacionalistas, no sentido de afirmar sua originalidade, autonomia literária e formar a "nação". Disto resulta a produção de saberes que emergem dentro de uma cultura política, contrapondo-se aos discursos da matriz cientificista que separa sujeito cognoscente do objeto a ser pesquisado, idealizando o conhecimento como verdade absoluta.

As revistas produzidas pela intelectualidade portuguesa constituíram-se em locais privilegiados de discussão acerca da escrita da História, da situação política, social, cultural e econômica de Portugal e das relações com outros países. Constituíram-se em veículos de propagação de idéias nacionalistas expressas na chamada lusitanidade, dirigindo-se com destaque para o Brasil. Entretanto, na relação com o Brasil, o que se travou foi uma luta política, na medida em que esta se manifesta quando homens e mulheres, mediante produção de conhecimento, operam no sentido de fazer valer a visão legítima do mundo social, buscando o reconhecimento pela produção e reprodução de capital simbólico que expressam notoriedade e respeitabilidade, afirmando sua autoridade e, por conseguinte, impondo ou criando condiçõ es para difundir e impor o conhecimento considerado legítimo e verdadeiro do sentido do mundo social, da sua significação atual e da direção em que vai e deve $i^{12}$. É neste terreno que se debatem alguns intelectuais portugueses e brasileiros. Assim, por exemplo, Sampaio Bruno, qualificado como filósofo português, publicou um livro, em 1898, intitulado Brasil Mental , mostrando a complexidade das relaçõ es entre Portugal, Espanha, Inglaterra e Brasil, no final do século XIX e início do século XX. Argumentou que sua preocupação ia no sentido de avaliar o desconhecimento que Portugal tinha do Brasil ${ }^{13}$. Do discurso de que Portugal desconhecia o Brasil comungavam também as revistas, embora algumas fossem publicadas com o objetivo de atender 0 público português. Ressalvas sejam feitas à revista Lusitânia, que nos seus objetivos anunciava querer comunicar-se com o Brasil e a Espanha, incluía seções específicas sobre o Brasil e, em parte referente à bibliografia, apresentava o Brasil por meio de resenhas de livros escritos por autores brasileiros.

Como o Brasil aparecia? Cada revista focou ou concebeu um espaço diferente para o Brasil. Assim, na revista Águia, somente no volume II do ano de 1912, apareceu a chamada "Secção Brasileira", com um artigo sobre Eça de Queirós e o Brasil. Depois, esta seção desapareceu e despontaram artigos com temáticas variadas como, por exemplo, "Portugal 
no Brasil". A partir de 1920, surgiu uma seção intitulada "Cartas ao Brasil" nas quais as preocupações básicas eram a emigração portuguesa para o Brasil e os desdobramentos do nacionalismo. Na seção "bibliografia" foram resenhados alguns livros de autores brasileiros, notadamente aqueles que fazem ligação entre Brasil e Portugal pelo passado comum. Na revista de História , o Brasil apareceu com mais freqüência, sendo-lhe conferido, às vezes, tratamento de cunho historiográfico mediante a publicação de documentos sobre o primeiro governador-geral do Brasil, de artigo sobre a expulsão dos holandeses e de resenhas de livros (principalmente de intelectuais que mantinham relações amistosas com Portugal), artigos sobre as relações luso-brasileiras, temas de história da história natural e etnografia brasílica. Na revista Lusitânia , o Brasil, em que pese o fato de ser considerado o interlocutor básico, juntamente com a Espanha, aparece muito mais como uma possibilidade de Portugal se ver nele mediante o reconhecimento da sua contribuição na formação da nacionalidade brasileira pela língua e pela literatura. Assim, por exemplo, despontam referências significativas às celebrações camonianas no Brasil pela Academia Brasileira de Letras e no espaço concedido pelas revistas a este evento. $\mathrm{O}$ Brasil é também visível em artigos que demonstram o desejo de realizar, com a ex-colônia, uma confederação luso-brasileira. Na Seara Nova 0 Brasil aparece como um lugar de investimento comercial e cultural e despontam preocupações com a emigração portuguesa. Os intelectuais levantaram algumas questões sobre esta problemática no sentido de Portugal, a exemplo de outros países, criar uma política emigratória. Era preciso ordenar a emigração de portugueses e criar condições favoráveis para os emigrantes no Brasil. Na revista Nação Portuguesa as referências ao Brasil são mais freqüentes. Nesta, o Brasil é o filho que "deu certo" e despontam artigo s que salientam a questão da língua, da literatura e da Igreja Católica na constituição das nacionalidades portuguesa e brasileira: declarando-se nacionalista, monarquista e de ten dência integralista, articula-se com intelectuais católicos, integralistas e monarquistas do Brasil.

A eclosão de quantidade significativa de revistas dessa natureza e a preocupação com o mundo da literatura, da escrita da história, com a língua e o papel destas na construção da nacionalidade, nos séculos XIX e $\mathrm{XX}$, fizeram parte do movimento nacionalista europeu que, segundo Hobsbawm, apresentava três critérios básicos para que um povo fosse classificado como nação: 1) existência de uma ligação histó rica a um Estado ou a um Estado que tivesse uma dimensão considerável e um passado recente; 2) existência de uma elite cultural que possuísse uma literatura na- 
cional e um vernáculo administrativo escritos; 3) capacidade provada para a conquista e neste caso, era extremamente importante ser um povo imperialista para que a população percebesse a sua existência coletiva. Disto infere-se a grande preocupação do mundo intelectual português em mostrar o repertório, a longa tradição e a penetração de sua produção, auto-representando-se como criador de nacionalidades, onde o Brasil se constituía como exemplo concreto.

Ao Brasil interessava, segundo alguns intelectuais, criar uma "língua brasileira ou nacional" e afirmar a originalidade literária. Sampaio Bruno argumentou com relação ao Brasil que "as coisas se transformaram em tanta maneira, e os sentimentos por tal jeito mudaram - que hoje, dos portugueses, os brasileiros nem a língua querem. É um cúmulo; mas é assim mesmo". Para tanto, registrou o autor, "envolvem-se em estudos gramaticais, manuseiam cotidianamente os clássicos quinhentistas, investigam minúcias dos lexicólogos”. Concluiu que, segundo os intelectuais brasileiros, "a língua brasileira já está suficientemente diferenciada do português, para se constituir à parte e reger de casa própria, como filha que se emancipou, repudia a norma paterna e pretende viver a boa vida, sem dar satisfações a uma tutela importuna e incômoda"14. A intelectualidade brasileira, nesse momento, preocupava-se também com os destinos do Brasil, diante da política expansionista européia e norte-americana, através dos chamados pangermanismo e panamericanismo. Diante destas circunstâncias emergiram algumas propostas. Segundo Sevcenko, a mais simplista delas sublinhava as dificuldades do presente e postulava transformar a sensação de inferioridade em um mito de superioridade: é o discurso da "ideologia do país novo" ou do gigante adormecido cuja grandiosidade dar-se-á no futuro. Outras propunham um mergulho profundo na realidade brasileira a fim de inventariar as características, os processos, as tendências, com a finalidade de encontrar uma alternativa ou diretrizes para a situação presente que possibilitasse uma avaliação concreta do futuro. A partir desta problemática é que os intelectuais canalizaram esforços para encontrar um tipo étnico expressivo da nacionalidade ou uma representação simbólica desta, que se constituísse em baliza para organizar e canalizar as reflexões tão heterogêneas da realidade brasileira ${ }^{15}$.

Se na Europa existiam Estados firmemente instalados, como a Inglaterra e a França, que investiam na sua consolidação enquanto nação imperialista, outros careciam de firmeza, como a Alemanha e a Itália, embora não se pudesse dizer que não houvesse um forte sentimento de identidade nacional. No Brasil, os intelectuais estavam convictos da exis- 
tência do Estado, mas não tinham certeza no que se refere à existência da nação. Dilema assumido, por exemplo, por Tobias Barreto e Joaquim Nabuco, denunciava a fragilidade do Estado brasileiro. Outra preocupação dos intelectuais brasileiros comprometidos com o ideal de construção da nacionalidade era a possibilidade de uma invasão por potências expansionistas, implicando na diminuição do território e perda da autonomia política. Espantados com o ritmo delirante com que as grandes potências procediam ao retalhamento do globo terrestre, com os quistos de imigrantes inassimiláveis que se formavam e cresciam em seu território, e com o próprio vazio demográfico de amplos espaços do país que assumiam a feição de uma terra de ninguém, disponível a qualquer conquista, políticos, jornalistas, cronistas e escritores assumiam uma postura de alarme e defesa, dando o melhor de si para aliviar a nação dessa aflição que em parte eles mesmos haviam gerado. Tais preocupações engendraram um tipo de nacionalismo vincado por uma política militarista de defesa do ternitório e das coisas nacionais, exarcebando-se com o final da Primeira Guerra Mundial.

Desencadeou-se, então, uma discursividade que primava pela urgência de conhecimento do Brasil, de penetração para o interior e expansão viária interna ${ }^{16}$. O nacionalismo dos intelectuais brasileiros apontava nessa direção. Não bastava a adesão ao saber técnico produzido na Europa, era preciso criar um saber próprio sobre o Brasil valendo-se de critérios cientificistas. Fomentar a adesão aos pressupostos científicos do século XIX e aplicar suas leis na leitura da realidade, produzindo instrumentos de análise, a exemplo dos conceitos, e informaçõ es objetivas sobre o país, eram os objetivos dos intelectuais. A produção de saber científico sobre o Brasil criaria condições de garantir-se o princípio de soberania e gerir com eficácia os seus destinos. A ciência tornou-se um instrumento de superação dos desequilíbrios gerados pela inoperância das elites tradicionais e criou condições para dar voz e vez aos intelectuais comprometidos com o ideal de salvação nacional. As representações que os intelectuais portugueses fizeram do Brasil nas revistas são de "gloriosa nação brasileira", "grande pátria do além-atlântico", "nação irmã", "herdeiro", "irmão de sangue e de gênio", "aliado natural", "moça e mais bela de todas as nações," "adolescente heróico," "filho do nosso orgulho e espelho" e "flor da nossa alma", "filho morgado", "povo novo", "país jovem". Estas representações, pelo menos as duas primeiras, conferiam ao Brasil seu status de nação, entretanto, sobressaem nelas imagens que enveredam para uma matriz de cunho biológico evidentemente referendadas pela perspectiva de que 
as relações humanas não se diferenciam da natureza. Sangue, raça, filho estão no ceme da matriz biológica apresentada pelo evolucionismo, redundando no chamado darwinismo social que, ao estabelecer a seleção das espécies, prescreve o predomínio natural das nações fortes e ditas civilizadas sobre as caracterizadas como primitivas, pelo saber etnocêntrico. Ao representar o Brasil como "adolescente", "povo novo", "jovem", "filho", Portugal estabeleceu uma relação vincada pela superioridade daquele que tem mais tempo de existência, hierarquizando a relação e relativizando seus impulsos de afirmação de soberania e identidade, porque o jovem, o adolescente, no receituário da psicologia evolutiva, carece de maturidade e experiência para to mar decisões acertadas; "filho e irmão" cria uma relação de tutela: 0 irmão de maior idade, na hierarquização e até no direito de primogenitura, goza de privilégios e o filho deve obediência aos que lhe deram origem (neste caso, os intelectuais portugueses, nas revistas, falam em "Pátria Mãe”).

A idéia da pátria-mãe está assentada no pressuposto daquela que dá origem, que descobre a outra, que a coloca no mundo e lhe lega um instrumento básico para suas relações: a língua. Portanto, as relações entre Brasil e Portugal dão-se sempre através de um discurso de poder no qual a língua comum e a escrita são para Portugal um instrumento de superioridade e de conquista; para o Brasil, a língua passa a ser objeto de luta e também de poder, quando os intelectuais se debruçam na busca de brasileirismos, propondo reformas gramaticais e orto gráficas, contrapondose à herança e sufo cando falares indígenas e africanos e, com isto, legitimando a distinção social pela língua falada e pela língua escrita. Existe, então, no Brasil, um desejo de marcar sua diferença não só pela literatura mas também por aquilo que lhe foi imposto: a língua.

\section{PoRTUGAL NO BRASIL MENTAL PELO DISCURSO LÍNGUA COMUM}

Manuel Múrias escreveu, em 1928, para a revista Nação Portuguesa um artigo intitulado A "Língua Portuguesa no Brasil”. Registrou que "ninguém já hoje perfila o conceito antropológico da raça, se reconheceu que não existe uma raça antropologicamente pura a não ser como abstração ou, quando muito, em tribos isoladas de selvagens ${ }^{1{ }^{17}}$. Esta conclusão não significava a inexistência de comportamentos racistas em Portugal naquele momento, quer internamente, quer na sua relação com o outro, evoluindo, mais tarde, para posturas eugênicas que buscavam o melhoramento racial/genético da população. Portugal certamente não poderia permanecer no paradigma da "raça branca pura" porque isto significaria 
alimentar uma contradição indefensável frente aos seus interesses colonialistas em África e também negaria seu passado no que se refere ao Brasil, onde a miscigenação era bastante significativa de norte a sul, com a total impossibilidade de criação de uma "raça branca pura". A argumentação de Renato de Almeida de que "não há como falar em uma raça comum, quando o caldeamento étnico produz tipos tão diversos dos portugueses ${ }^{\prime 18}$ marcou o dissenso na medida em que chamou a atenção para a especificidade do Brasil no que se refere à miscigenação. Por que neste momento era importante para Portugal falar em raça comum?

Esse foi um dilema com o qual muitos intelectuais brasileiros defrontaram-se a partir da leitura de paradigmas racistas europeus. Os intelectuais, a partir do final do século XIX, ligados à sociologia, antropologia, história, medicina e literatura começavam a reelaborar as teorias racialistas no sentido de apostar na miscigenação como forma de atingir o máximo branqueamento possível da população brasileira. De qualquer forma, a questão racial desponta como algo que circula por dentro da constituição e ao aprimoramento da língua em Portugal e no Brasil, pois admitese a contribuição de africanos e índios na língua, mas a dita língua erudita prescindia desta influência e devia afirmar-se tendo como referencial os clássicos e as normas gramaticais. Afirmava Manuel Múrias que "se, como judiciosamente notou na Esquisse d'une dialetologie portugaise, o senhor doutor J. Leite de Vasconcelos, chamamos dialeto ao falar próprio de Trás-os-Montes, por exemplo, não há razão para evitarmos este termo falando do Brasil...no que respeita à linguagem popular do Brasil, não há dúvidas tratar-se de um dialeto, outro tanto se não dirá da língua empregue pelos melhores escritores brasileiros". Sua argumentação no que se refere à relação língua popular e língua enudita vai no sentido de que "essa língua em que se escrevem os monumentos artísticos da nação, com a qual se fixam as ações e os feitos de seus homens de ciência e de guerra, em suma a sua história, estudasse nos clássicos, muito mais do que no povo, e com razão porque representa um depuramento da língua popular, um esforço artístico realizado pelos escritores sem a direta intervenção do povo. Na literatura enudita subsiste em regra mais enérgica a influência da literatura mãe, a qual continua a sua missão coordenadora na luta de manter a hegemonia"19.

No Brasil, durante as últimas décadas do século XIX e Primeira República, os intelectuais investiram na produção intelectual que se contrapusesse ao discurso de que a língua falada e escrita no Brasil constituía um dialeto. Para isso faziam críticas ao biologismo e ao nacionalismo, 
propondo análises baseadas em critérios científicos. Dessa forma, os intelectuais brasileiros, a partir das primeiras décadas do século XX, visando fugir dos cânones da filologia comparada ou do chamado clacissismo, investiram na chamada dialetologia, tendo como método a geografia lingüística. Um dos livros que marcaram esta perspectiva no Brasil foi o Dia leto Caipira de Amadeu Amaral, datado de 1920, e do qual a revista Águia pública uma resenha feita para o Jornal do Brasil registrando que

"o mérito do Senhor Amaral mais aumenta e mais se ilustra, quando volve o olhar para dentro da nossa terra e de lá traz, a exibir na poeira luminosa das cidades, um reflexo do viver, do sentir e do falar da nossa gente, dessa gente simples, de moral sadia, honesta e humilde até no pitoresco articular das suas expressões. Essas expressões que chegam aos centros civilizados com o falso nome de 'vícios de linguagem', e logo se depreciam... ${ }^{20}$ ".

Certamente alguns intelectuais brasileiros repensaram a abrangência da linguagem literária no que se refere ao distanciamento desta dos falares do povo, pois, "numa língua, o que fala, e que não cessa de falar num murmúrio que não se entende, mas donde lhe vem, no entanto, todo 0 fulgor, é o povo”21. Infere-se ainda que este debruçar sobre os falares regionais no Brasil tem também suas condições de emergência no interior do pensamento racista, neste momento, marcado pela discussão sobre 0 papel da miscigenação na sociedade brasileira, fortemente defendido por Sílvio Romero, que só acreditava na existência de uma literatura brasileira pela ação transformadora do mestiço na poesia popular.

Renato Mendonça escreveu um livro intitulado O português no Bra sil, em 1936, no qual historicizou a produção intelectual brasileira acerca da temática brasileirismo. O livro é um libelo em defesa da existência de uma língua brasileira e uma contraposição acirrada à idéia defendida por J. Leite de Vasconcellos em Esquisse d' une dialectologie portugaise. Disse o autor que o português e a língua falada no Brasil "são duas línguas vivas que só se encontram num passado remoto de vários séculos. $\mathrm{Ou}$ avistam-se telescopicamente através da língua literária falada em Portugal e da sua imitação lusitanizante do Brasil”22. Renato Mendonça mostrou o investimento da intelectualidade brasileira no que se refere à problemática da língua e, com isso constituiu uma mostragem do dissenso na relação com Portugal, pois, nesse momento, o nacionalismo considerava a existência de um idioma próprio como condição sine qua non para um país se constituir enquanto nação. Isto significava que no reino da 
língua falada e escrita havia um "parentesco muito forte entre linguagem e o livre destino dos homens ${ }^{\prime 23}$.

Múrias, ao registrar suas idéias sobre a língua e a literatura no Brasil, desenvolveu seu raciocínio mostrando a influência das produções literárias por meio da escola, da imprensa e dos meios de comunicação na vulgarização do idioma, propondo que se estudasse a língua nos clássicos, muito mais que no povo, porque os clássicos representavam um depuramento da língua popular. Portanto, no seu entender a língua popular não é a mesma da origem, podendo ser considerada um dialeto. Este termo, dizia o autor, "belisca os ouvidos de alguns brasileiros". E concluiu: após citar destaques da literatura brasileira e comentar a crítica literária feita por José Veríssimo, que "de qualquer forma, porém, o que é necessário acentuar é que o Brasil conta hoje com uma tradição literária interessante e distinta que seria preciso torcer para realizar uma diferenciação lingüística que lhe permitisse construir uma literatura autônoma, até na língua. Lucrará o Brasil com essa separação lingüística? Não. Para o Brasil a língua portuguesa, criando em terras americanas um outro significado nacionalista, é verdadeiramente a língua brasileira ". A temática deste artigo de Manuel Múrias não se constitui em voz isolada no conjunto das revistas consultadas e permite constatar-se o quanto era significativo para setores da intelectualidade de Portugal, afirmar o caráter natural da relação com o Brasil e positivar a ação colonizadora por meio da língua. A discursividade em torno da língua comum, vista como "criação espontânea da raça," constituiu-se em um instrumento de poder. Aos historiadores, fazendo uso do que escreveu Bourdieu, não é permitido esquecer que "a experiên cia primeira no mundo (...) é uma relação socialmente construída, tal como os esquemas perceptivos que a tornam possível”24.

A Portugal interessava afirmar esta relação por meio da chamada "língua comum", na medida em que é através dela que um país pode expressar, difundir e imprimir sua produção cultural e concretizar seus interesses comerciais e industriais. Portanto, tal discurso constituiu-se num veículo fundamental para Portugal afirmar sua grandiosidade e notoriedade perdidas, pois no final do século XIX e começo do XX estava correndo o risco de morrer de concorrência. Além disso, permitia-lhe afirmar seu poderio imperialista e legitimar o colonialismo, qualificando esta prática na medida que se via como criador de nação ou de nacionalidade. Não se pode, entretanto, esquecer que "a linguagem (...) forma o lugar das tradições, dos hábitos mudos do pensamento, do espírito obscuro dos povos; acumula uma memória fatal que nem mesmo se conhece 
como memória”25. Para alguns intelectuais brasileiros, envolvidos na construção da nacionalidade, interessava afirmar cada vez mais a autonomia no que se refere ao relacionamento intelectual e envolviam-se calorosamente no projeto de criação de uma literatura dita genuinamente nacional.

Desejavam os intelectuais brasileiros "abrasileirar" a língua enquanto código fundamental de expressão de um povo, a qual nos requisitos exigidos pelo discurso nacionalista, era uma característica importantíssima a ser levada para a constituição de uma nação e para a conseqüente afirmação da identidade nacional. No interior deste dilema, os intelectuais brasileiros marcaram suas produções objetivando a construção de uma identidade nacional, tendo em vista serem eles os sujeito s responsáveis pela criação da nação, enquanto "comunidade imaginada" e, ao mesmo tempo estes são constituídos dentro do aparato simbólico nacionalista e, com isto, "operavam uma dupla naturalização que resulta da inscrição do so cial nas coisas e nos corpos tanto daquele que domina como dos que são dominados"26.

Percebe-se nas revistas certa preocupação com os desdobramentos das práticas nacionalistas e, com base na experiência ancestral e berço dos clássicos, percebe-se a intenção de apontar a direção que a ex-colônia tomava. Mais que isso: o caminho que ela devia seguir. Em 1920, na revista Águia, na seção Carta ao Brasil , afirmou-se que os elementos comuns de cultura dos diversos povos, principalmente a unidade espiritual com as gentes européias que lhes deram origem- Portugal e Espanha -, é bem maior do que imaginam certos amadores dos costumes e das falas regionais. Cita-se o livro de Crispim Mira, Minha terra, minha gente, que tornaria seus leitores mais nacionalistas, e alerta-se para o seguinte: "esta bela página deixa a desejar uma única coisa: substituir pela velha e honesta palavra 'patriota' o ambíguo, o camaleônico termo nacionalista"27. Para a intelectualidade portuguesa parecia estar acontecendo uma segunda independência do Brasil quando seus intelectuais se debruçavam na discussão sobre a criação de uma língua brasileira, principalmente no que se refere às pesquisas em torno do brasileirismo e da criação de uma literatura genuinamente nacional. Assim, a revista Águia registrava a publicação de um estudo de Miguel de Toro y Gisbert intitulado "Reinvindicacion de Americanismos", no qual o autor afirmava que:

"tais americanismos eram de muito bom e muito velho espanhol. O mesmo sucede com os brasileirismos. Expressão que oiça na boca de um brasileiro, palavra que topamos numa página escrita no Brasil, e que não conhecemos como portuguesa de Portugal, logo apressadamente lhe estampamos 
com o rótulo de brasilerismo. Quando aparecerá um Toro nosso, a dar-nos uma reivindicação de brasileirismo" ${ }^{28}$ ?

Tais preocupações imbricam-se a outros interesses e, isto José Osório de Oliveira deixou bastante explícito ao afirmar: "mesmo que não houvesse razões de ordem econômica e de política internacional a impedir a sua efetivação, bastava o divórcio mental em que os brasileiros estão do nosso país para tornar impossíveis todas as outras políticas..." ${ }^{29}$.

Sampaio Bruno contrapôs-se com veemência aos propósitos dos intelectuais brasileiros em investir na tentativa de criação de uma "língua brasileira", revelando seu pendor racista e elitista quando registrou que:

Ora, se o brasileiro não quer ser português, que quer ser?Quer ser tupi, como os falares dos indígenas de suas selvas? quer pertencer ao grupo das línguas bantus, que são as em que se expressa variedade pretalhada que 0 tráfico vasou nos portos de Santa Cruz? Mas essas línguas são línguas aglutinantes, aglomerativas, como lhe queiram chamar; em todo o caso, línguas de tipo rudimentar e inferior. Passar de uma língua de flexão para uma língua holofrástica; desprezar uma língua novilatina para dar preferência a uma língua cafreal ou da costa do ocidente da África - seria ir de cavalo para burro. E para burro dos por isso chamados silvestres, isto é, aqueles que deixam o pasto dos lameiros, para retouçar os cardos das silvas ${ }^{30}$.

Certamente a intelectualidade brasileira envolvida nas questõ es lingüísticas norteava-se também por critérios racistas e elitistas, pois, nesse momento, operava-se no país, principalmente nos grandes centros, uma política cultural que objetivava reformular as condutas e as sociabilidades, pautando-se nos princípios médico-higienistas pelo qual tudo o que fosse considerado desvio, rústico, degenerado não se constituía em exemplo a ser seguido. O que fosse levantado como legado cultural seria classificado pelos arautos do folclore e transformado em peça de museu, como parte de um passado morto. Também as manifestações culturais eram selecionadas a partir desses princípios antropológicos. Certamente os falares indígenas e de descendentes de africanos eram levados em conta como legado cultural, mas nunca fazendo parte da linguagem erudita. Como bem registra Eni Puccinelli Orlandi, missionários, viajantes e pesquisadores, nas suas menções, aperfeiçoaram a língua dos índios em direção ao ideal da gramática ocidental. No conjunto, todos produziram a domesticação da língua indígena pela gramática ocidental cujo modelo é o latim ${ }^{31}$. 
Portugal NO BRASIL MENTAL AO LONGO DA LITERATURA

Esta festa (Centenánio da Independência - 1922) erguendo o orgulho colonial, amesquinhou o espírito nacional ${ }^{32}$.

A crítica literária brasileira investiu na criação e no apoio ao espírito literário nacionalista. Assim Araripe Júnior, escritor e crítico brasileiro, escreveu uma série de artigos intitulados "Lucros e Perdas" (1883) e, em um deles, fez referência às relaçõ es entre Portugal e Brasil. Iniciou o artigo escrevendo que apareceu em Portugal uma publicação intitulada Revista dos Estudos Livres. Atribuiu suas idéias a Theóphilo Braga, escritore político português, e reproduziu as intenções da revista:

Na crise de transformação mental e política em que vão entrando as duas nacionalidades portuguesa e brasileira, filhas da mesma tradição histórica, nas quais o regime católico monárquico subsiste pela inércia, mas sem apoio nas consciências, é imensamente necessário um órgão crítico e especulativo que agremiasse os dois povos para a inteligência de sua transição inevitável... A revista procura reatar a aliança mental luso-brasileira; eis o seu fim prático, resultante do atual momento histórico ${ }^{33}$.

A seguir, o escritor considerou-a um produto da mais completa ignorância no que se referia ao conhecimento dos elementos que constituem a nação brasileira. Entendia não ser suficiente saber a composição racial do povo para produzir uma fórmula ideal. Seria preciso vê-lo em movimento, vivo e em ação; não basta conhecer a anatomia do ser humano, seria preciso acompanhar o seu desenvolvimento fisiológico. Descarta assim a possibilidade do reatamento da aliança mental luso-brasileira através de quatro argumentos ${ }^{34}$. Embebido pela cultura política nacionalista, racionalista, determinista e naturalista, a partir de Taine, Buckle, Spencer etc, Araripe Júnior foi contundente em sua crítica assentada numa perspectiva sobejamente anti-colonialista que entendia a proposta de aproximação como possibilidade de uma recolonização mental do Brasil. O dissenso, em Araripe Júnior, estava em defender-se que não seria a tradição o principal fator da composição do espírito brasileiro seria, antes sim, o ponto de vista que coordena as obras do espírito e lhe orienta o valor científico ou literário. A questão da literatura nacional só poderia ser resolvida pela concentração das vistas no meio físico, único valor estável da nossa história, único que não sofre solução de continuidade. Porém, não o principal, pois não haveria um que mais se destacasse que 0 da raça portuguesa arrastando para dentro deste meio todos os acúmulos 
de sua civilização. Para quebrar a importância desse fator, afirmou ser mais favorável à qualidade do que à quantidade e apostou na importância do particular sobre o geral. "Na história universal, não resta dúvida que o Brasil é - Portugal atravessando os mares, procurando um novo habitat e transformando-se ao influxo de variadíssimas influências" ${ }^{\prime \prime 35}$.

Theóphilo Braga respondeu às críticas de Araripe Júnior mostrando a dissidência que houve entre esse autor e Silvio Romero, comparando "Lucros e Perdas" com as "Farpas" de Ramalho Ortigão. Assentou sua resposta, primeiramente, na recriminação das dissidências, pois, como bom positivista, interessava-lhe a harmonia e o que existia no Brasil não era criação brasileira, mas imitação dos Estados Unidos.

"A aversão das colônias americanas pela Inglaterra, motivada por causas históricas, tem sido por vezes parodiada no Brasil, mas é um desabafo individual em jornais ou qualquer outra folha. $\mathrm{O}$ fato positivo é que o Brasil precisa de todas as atividades e aquele que perturba essa convergência civilizada, assoalhando antipatia de raça quando a miscigenação acabou com elas e ódios históricos sem validade nos fatos, pratica um ato estéril, mas nem por isso deixa de ser condenável. Aplicar no Brasil esta aversão pelo elemento português é uma leviandade. Se porventura na população brasileira se eliminasse por certo tempo o elemento português a população regressava ao elemento selvagem. É isso que demonstra a Antropologia. De todos os povos da Europa só o português, o italiano e o espanhol é que podem adaptar-se ao clima da América Meridional".

Afora a intenção de defesa em relação à crítica feita por Araripe Júnior, percebe-se no texto a busca de respeitabilidade e notoriedade e Theóphilo Braga, colocando-se como voz autorizada, indicou o caminho político a ser seguido:

“O Brasil só pode ser grande como povo civilizado quando se reorganizar em uma república federal com vida própria e na intensidade de suas energias tendo a autonomia local, fortalecendo-se um pacto voluntário de união em uma meta, e não sob essa pressão centralista irracional e ineficaz ${ }^{136}$.

Desta observação infere-se que "Portugal no Brasil Mental" estava também relacionado com problemáticas levantadas pelas revistas, no tocante à questão da emigração portuguesa. Ora, segundo a revista Àguia , de 1908 a 1919 emigraram para o Brasil 386.686 portugueses, número seguido pelos espanhóis-212732, sendo que em 1920 emigraram 22.277 por- 
tugueses. As revistas preocupavam-se com a falta de uma política emigratória por parte de Portugal e também com o destino dos emigrados para o Brasil. Registrava a Àguia que: "Portugal chora os mortos, canta as suas glórias, exagera morbidamente a justíssima homenagem ao soldado desconhecido (...) e não trata dos vivos, nem das razões da vida" ${ }^{37}$. Não era a todos os vivos que Portugal dispensava mau tratamento. Os ricos comerciantes de vinho, de azeite, banqueiros, entre outros, recebiam atenção especial e as políticas entre Brasil e Portugal eram encetadas a partir das investidas destes setores através das embaixadas, associações comerciais e industriais que formavam a parte mais significativa das relações internacionais entre os dois países. A grande maioria dos emigrados portugueses, analfabetos e sem qualificação profissional, compunham o quadro das emigrações européias para o Brasil. No entanto, muitos portugueses, pelo passado colonial e pela tradição dele decorrente, dedicavam-se às atividades comerciais com o intuito de formar lastro econômico e mais tarde retornar a Portugal, formando para tal no Brasil poderosas associações, principalmente no Rio de Janeiro e em São Paulo.

Não se pode deixar de levar em consideração que nesse momento a Europa como um todo despejava seu excesso populacional no Brasil, e seus governos assumiam uma posição firme em relação aos destinos dos emigrados. Pode-se perceber que ao estimular a emigração, estes países, na sua política imperialista, também objetivavam expandir-se e garantir seus interesses no Brasil, como foi o caso da Alemanha, da Inglaterra, da Itália e da França. Alemanha e Itália já haviam vomitado contingentes populacionais no século XIX e nesse momento procuravam resguardar seus interesses comerciais e culturais. A Inglaterra investira grande quantidade de capitais na construção de estradas de ferro e energia elétrica, sem levar em conta que desde a abertura dos portos passara a ser soberana no comércio com a colônia portuguesa e com o Império brasileiro. Carlos Malheiro Dias expressa esta preocupação ao referir-se ao problema da emigração portuguesa para o Brasil, em uma conferência intitulada $\mathrm{Ru}$ mo à Terra, que aparece transcrita na revista Águia com o sugestivo título: "O problema da colonização portuguesa no Brasil". O problema está, registrou Carlos Malheiros Dias,

"no fato da colônia portuguesa ter se dedicado ao comércio do litoral e do Brasil ter descoberto que a sua vocação é a agricultura. A política portuguesa deve ser aproveitar as condições favoráveis de ação no Brasil- existência de uma comunidade de língua e de raça- retomando o rumo da terra, se não fizer a colônia portuguesa no Brasil está condenada ao desaparecimento, 
como aconteceu à colonização de Santa Catarina que estava nas mãos dos primitivos ilhéus. Mas logo que o interior do estado começou a povoar-se com as prolíferas raças louras na Europa central foi se germanizando o comércio" ${ }^{138}$.

A sugestão da revista é uma contraposição às colônias alemães e italianas existentes no Brasil, pois sugere que se

"siga a idéia da Companhia de Colonização Agrícola que projetou a organização de uma grande companhia agrícola com capitais portugueses para a fundação de colônia que teriam os nomes das províncias de Portugal e onde se instalariam convenientemente os imigrantes rurais, criando núcleo de povoamento expansivo"39.

Certamente a exemplo de Blumenau, Joinville, Brusque, Wittemarsun, Hamonia, Nova Trento, Nova Veneza, Alfredo Wagner, Novo Hamburgo, etc, teríamos Trás-os-Montes, Lisboa, Évora, Alentejo etc.

No século XIX, houve no Brasil o desejo consciente de se firmar uma produção literária que fosse reconhecida como representante ou fundadora da nacionalidade. Esta prática não esteve isenta de avaliações por parte de expoentes da crítica literária européia. Assim, por exemplo, João Baptista da Silva Leitão de Almeida Garrett, em "Bosquejo da Histó ria da Poesia e Língua Portuguesa”, preâmbulo da coletânea considerada por Almeida Garrett, o Parnaso Lusitano , de 1826, avaliou a produção de alguns autores nascidos ou vividos no Brasil no século XVIII, atendo-se marcadamente em Cláudio Manuel da Costa e Tomaz Antonio Gonzaga e também nos épicos de José Basílio da Gama, O Uraguai e de Santa Rita Durão, com destaque para Caramuru. Teceu as seguintes considerações: para Cláudio Manuel da Costa, português, atribuiu "mui distinto lugar entre os poetas portugueses da época," ou seja, da restauração das letras em Portugal. Para o Frei José de Santa Rita Durão, na obra Caramuru , destacou o tratamento dado à morte de Moema, dizendo que:

"Notarei, por exemplo, o epsódio de Mohema, que é um dos mais gabados, para demonstração do que assevero. Que belíssimas coisas da situação da amante brasileira, da do herói, do lugar, do tempo não pudera tirar o autor, se tão de leve não houvera desenhado este, assim como outros painéis? ${ }^{\prime 40}$.

No que se refere a Tomaz Antonio Gonzaga, Garret advertiu deixou 
de explorar as sugestões oriundas do meio americano, assim expressando-se:

"Se houvesse por minha parte de lhe fazer alguma censura, só me queixaria, não do que fez, mas do que deixou de fazer. Explico-me: quisera eu que em vez de nos debuxar no Brasil cenas da Arcádia, quadros inteiramente europeus, pintasse os seus painéis com as cores do país onde os situou (...)”.

José Basílio da Gama, autor de Uraguai, para Garrett foi

“(...) o sensível cantor da infeliz Lindóia que mais nacional foi que nenhum de seus compatriotas brasileiros. Cenas naturais muito bem pintadas, de grande e bela execução descritiva; versos naturais sem ser prosaicos, e quando cumpre sublimes sem ser guindados; não são qualidades comuns" (...) Os brasileiros lhe devem a melhor coroa de sua poesia, que nele é verdadeiramente nacional, e legítima americana" ${ }^{\prime 41}$.

Esta avaliação de Almeida Garrett teve adesões mas também encontrou oposições. Francisco Adolfo de Varnhagen publicou em 1850, em três volumes, a obra Florilégio da Poesia Brasileira . Tal obra constitui um libelo em favor da literatura nacional, portanto, um documento que tem suas condições de emergência no movimento nacionalista brasileiro, em que a literatura assumiu uma posição de destaque enquanto criadora de linguagem simbólica formadora e dignificadora da nação. No prólogo do Florilégio, Varnhagen anunciou seu embate com alguns intelectuais quando iniciou a primeira linha com a expressão "Inimigos do monopólio literário" ${ }^{42}$. Mais adiante colo cou que "não chamamos Parnaso a esta coleção, pelo mesmo motivo de estarmos um pouco em briga com a mitologia, e por devermos distingui-la de outra anterior, que leva aquele título". Ao final do prólogo Varnhagen entrou na discussão a respeito da separação das literaturas brasileira e portuguesa pelo critério da língua registrando que:

Aqui desejaria alguém que entrassemos na questão da divisibilidade das literaturas portuguesas e brasileiras, o que vários julgam impossível, em conseqüência da uniformidade da língua. Repugnará sempre o nosso ânimo entrar em tal questão; por nos parecer que os argumentos de parte a parte poderão correr o risco de sair pedantes, ou demasiados escolásticos, sem falar dos mal entendidos preconceitos de amor próprio nacional numa questão literária.

Seja-nos porém, permitido deixar aqui consignadas algumas dúvidas, cuja 
solução oferecemos aos que neguem a possibilidade - a naturalidade da divisão das duas literaturas.

1. Deverão deixar de figurar, nas histórias literárias da Prússia e de Portugal, as obras dos eminentes escritores Humboldt e Pinheiro Ferreira, só porque estes, para terem mais leitores, as escreveram em francês?

2. Desalistaram-se da literatura portuguesa o bispo Osório e Paiva de Andrada, porque escreveram em latim?

3. É, por ventura, tão verdadeira, tão estrita essa identidade de língua? Não há no Brasil nomes do pais ali conhecidos, e cujo objeto é mais ou menos poético, dos quais em Portugal a sua pronunciação dizem que excita o riso? Lembremos dos receios que neste sentido tinha o autor do Caramuru ao publicar o seu poema, e lembremo-nos mais do que certo censor tinha de que provocassem o riso tantos nomes do Brasil como jacarandá, palavra esta em que há nada menos de quatro $\mathrm{aa}^{43}$.

Varnhagem conclamou os intelectuais a se inspirarem da poesia que brota com tanta profusão do seio do próprio país, a buscarem a originalidade e serem americanos. Contudo, isto não significaria seguir o que se fez nos Estados Unidos, "uma revolução dos princípios, insubordinação aos clássicos gregos e romanos e dos clássicos da antiga mãe-pátria”. Perguntou se não seria um engano querer-se ostentar patriotismo "exaltando as ações de uma caterva de canibais". Varnhagem, como legítimo representante do Instituto Histórico e Geográfico Brasileiro, estava comprometido em edificar uma história nacional onde o africano ou seu descendente e o índio compunham harmonicamente a história nacional, na qual prevalecia a herança branca advinda dos colonizadores de estirpe. Como disse Machado de Assis estabelecendo o dissenso com o historiador, "os que, como Varnhagen, negam tudo aos primeiros povos deste país, eles podem lo gicamente excluí-los da poesia contemporânea (...) depois das memórias que a este respeito escreveram os Srs. Magalhães e Gonçalves Dias, não é lícito arredar o elemento indiano da nossa aplicação intelectual. Erro seria constituí-lo um exclusivo patrimônio da literatura brasileira; erro igual seria sua absoluta exclusão". Nas discussões sobre o nacionalismo na literatura Machado de Assis distanciou-se do lugar comum, indo para além do localismo quando registrou que

"não há dúvida que uma literatura, sobretudo uma literatura nascente, deve principalmente alimentar-se dos assuntos que lhe oferece a região; mas não estabeleçamos doutrinas tão absolutas que a empobreçam. O que se deve exigir do escritor, antes de tudo, é certo sentimento íntimo, que o torne ho- 
mem do seu tempo e do seu país, ainda quando trate de assuntos remotos no tempo e no espaço" ${ }^{\prime 4}$.

Voltando às colocações de Varnhagen ainda no prólogo de sua obra procurou marcar diferença no que se refere à forma como Almeida Garrett apresentou o seu bosquejo registrando que "como não tratávamos de oferecer modelos de arte poética, preferimos, em lugar do método do Parnaso Lusitano, o de apresentarmos as poesias pela ordem cronológica dos autores, cuja biografia precedesse sempre as composições de cada Um". Contrapõe-se à preferência de Garrett pela epopéia de Basílio da Gama, O Uraguai, em detrimento do Caramuru , de Santa Rita Durão. Para Varnhagen, o poema Caramuru "oferece um tipo de resignação cristã e de virtudes conjugais... O Caramuru ganhará, de dia para dia, mais partido, e chegará talvez a ser um dia popular no Brasil". Sobre O Uruguai registrou que "esta epopéia é das modernas de mais merecimento, se bem que o autor com a pressa não lhe desse todo o desenvolvimento. José Basilio tinha se familiarizado com a literatura clássica italiana, e deixou nisso freqüentes reminiscências". O Uraguai contesta a política adotada pelos jesuítas no que se referia à liberdade dos índios americanos, e a epopéia, praticando a ideologia do Marquês de Pombal, transforma-se em violenta diatribe contra os inacianos, à época recentemente expulsos de Portugal. Na História Geral do Brasil , Varnhagen registrou que:

"O Caramuru é mais acabado que o Uraguai. A dicção é clara e elegante; a metrificação natural, e em moralidade um modelo de resignação cristã e de virtudes conjugais. Não falta quem acoime o poema de menos nacional, pela circunstância de ser europeu o seu herói, o que vale quase tanto como chamar troiana a Eneida, que não é mais que o poema da civilização da terra lavínia, como o nosso é da terra brasílica" ${ }^{45}$.

Outros críticos posicionaram-se contrários aos juízos de Garrett, a exemplo de Santiago Nunes Ribeiro que escreveu Da Nacionalidade da Literatura Brasileira . Benjamin Franklin Galvão no ensaio Literatura , de 1863, também questionou as considerações de Almeida Garrett ${ }^{46}$. Pode-se dizer que as observações de Almeida Garrett provocaram uma série de controvérsias e adesões, estabelecendo dissenso do demonstrar que a escrita, enquanto prática política, desencadeia possibilidades de partilha do mundo sensível onde a visão e a divisão do mundo das idéias, das motivações políticas mobilizam homens e mulheres no sentido de le- 
gitimarem ou não imaginários necessários à constituição da nação enquanto "comunidade imaginada" ${ }^{47}$.

Contemporâneos de Almeida Garrett, Ferdinand Denis e F. Wolf também se posicionaram em relação à literatura brasileira. 0 primeiro no livro Résumé de l'Histoire Littéraire (1826) e Scènes de la nature sous les tropiques (1824); e o segundo em Le Brésil littéraire. Histoire de la litté ratur e brésilienne (1863). A natureza, para os viajantes europeus, foi resignificada como demonstrativo de nostalgia no que se refere aos paradigmas europeus de sociedade e cultura, constituindo-se em espaço de avivamento da memória no que se refere aos encantamentos da sua pátria distante. $\mathrm{O}$ olhar europeu para o que deveria ser a manifestação da literatura brasileira foi feito a partir de leituras acumuladas de saberes de cunho biológico, nacionalista, racista, eurocêntrico e imperialista, no qual o Brasil tornou objeto de imaginação para criar epítetos de glorificação da sua pátria. Suas leituras pouco percebem a presença da contribuição portuguesa, mas mostram a constituição de uma "raça" que se distingue e que aponta para a criação de autonomia no que se refere ao colonizador. Em contrapartida, ensejam uma dependência da intelectualidade brasileira no atinente ao fornecimento de cânones desejáveis para a constituição de uma literatura nacional colados nas matrizes de produção de saberes, apontadas acima.

A polêmica entre intelectuais brasileiros e portugueses ficou mais acirrada quando Camilo Castelo Branco publicou, em 1879, o Cancionei ro Alegre de poetas portugueses e brasileios e, em seguida, Os Críticos do Cancioneiro Alegre, em 1879. Na introdução ao Cancioneir o fez uma análise da sua situação frente aos novos encaminhamentos literários, estabelecendo causas para o fim da poesia amorosa. Não foi a modernidade que a tudo desencantou. Ela acabou porque "já não existem poetas que exercitem a arte por amor da arte e não existem mulheres que sintam no peito o vácuo dos soneto ${ }^{\prime \prime 48}$. Quanto aos poetas brasileiros, Camilo despejou a sua verve, a sua ironia destroçadora e deixou manifesto ter sido um homem forjado na cultura política do nacionalismo e do colonialismo. Comentou a produção de Fagundes Varela, de Francisco Moniz Barreto, de Joaquim de Sousa Andrade, de Caetano Filgueiras de Casimiro, de Abreu e de Álvares de Azevedo e Franco Sá. Para estes últimos registrou que

"assim procederiam os brasileiros, se o sol lho contivesse, e o grito do Ipiranga os não desconchavasse da nossa familiaridade. Fzeram mal. Nós havíamos de engordá-los, envolvê-los de famílias, e do bom sol que por aqui 
nos aquece moderadamente a velha castidade da Lua, e dar-lhes finalmente alfândegas na Metrópole e o exemplo saudável dos nossos amigos Vidal e Alexandre Montero" ${ }^{\prime \prime 9}$.

Os ecos de crítica ao Cancioneiro Alegre no Brasil são visíveis no texto de Bruno Sampaio e de Fidelino de Figueiredo na revista de História. Porém em Críticos do Cancioneiro Alegre, Camilo Castelo Branco revelou a amplitude dos conflitos que a avalição atingiu, e também seu pendor racista, eurocêntrico, naturalista veio à tona. Ao referir-se à carta de Tomás Filho que lhe retribui às criticas feitas aos poetas brasileiros, Camilo diz que:

"Pedro Álvares Cabral encontrou o Brasil; eu estou descobrindo os tolos de lá! Ele achou o selvagem nu, estreme, sinceramente boçal; eu descubro o caboclo Tomás besuntado de literatices francesas que não lhe modificaram plasticamente a proeminência dos ossos temporais, a estreiteza da testa, os ângulos faciais, o canto externo do olho convergindo para o nariz chato, a amplidão das ventas, a espessura carnuda dos beiços, as finuras das pantorrilhas, a lucidez da pele cobreada que esvurna catinga, uns longos de carapina, e a indigência da barba".

Para Artur Barreiros, que lhe escreveu uma carta de oito páginas, respondeu:

este sujeito escreve-me que tem uma excelente bengala de Petrópolis com a qual me baterá, se eu for ao Brasil admirar os cérebros de tapioca. $\mathrm{O}$ mulato estava a brincar; eles tem a debilidade escangalhada do sangue espúrio, escorrido das podridões das velhas colônias que de lá trouxeram à Europa a gafaria corrosiva; às vezes excitam-se bastante com a cerveja ordinária, têm então ímpetos imoderados, dão guinchos, fazem caretas, coçam as barrigas, exigem banana, cabriolam se lhes atiram ananás, e não fazem mal à gente branca" ${ }^{\prime 5}$.

Esta maneira jocosa de responder à crítica, com um pendor fortemente racista e colonialista, revela que os intelectuais das diversas artes são filhos de seu tempo e incorporam, muitas vezes sem se dar conta, discursos produzidos no interior da sociedade, mas não se pode deixar de levar em consideração a existência de formas discursivas dissonantes que partilham o mundo sensível segundo outras perspectivas. Isto significa que homens e mulheres também fazem opções no interior do mundo das 
idéias, muitas vezes por força da chamada tradição que é componente da cultura política, não se dando conta do significado político de suas escolhas. Em Camilo Castelo Branco, a cultura política do nacionalismo tomou conta de sua maneira de ser e de olhar o mundo, assim como de muitos outros intelectuais brasileiros. Ele cultivou em sua memória o desejo de permanência dos tempos áureos do colonizador, visível nos comentánios feitos a Álvares de Azevedo.

As polêmicas entre Portugal e Brasil foram alimentadas quando os intelectuais brasileiros valiam-se das leituras feitas por viajantes e críticos literários de outros países europeus, não fazendo referência à contribuição portuguesa para a literatura brasileira. Carlos França, intelectual português, escreveu um artigo na revista de História demonstrando que os portugueses, logo no século XVI, deram à colonização uma feição científica acentuada. Não só introduziram no Brasil, logo após a descoberta, inúmeras plantas úteis e animais domésticos e criaram indústrias que prosperaram, mas também trataram de divulgar, por escrito, o que de famoso havia na terra que descobriram ${ }^{51}$. Em outro artigo, na mesma revista, Carlos França retomou a discussão colocando ser de se lamentar que na etnografia autores brasileiros, dos mais categorizados, recorram a escritores estrangeiros do século XVI, os quais não raro deturparam, por não compreender, aquilo que os portugueses do século XVI averiguaram e descreveram. Fazia referência às obras de Pero Magalhães Gandavo e de Gabriel Soares de Sousa, aos escritos dos jesuítas portugueses sobre 0 Brasil, ao tratado do matemático Pedro Nunes, aos roteiros de D. João de Castro e as Crônicas de África e da Ásia, qualificando-as pelo seu caráter científico $^{52}$. Fidelino Figueiredo, na revista de História reafirmou o pendor científico dos ciclos das navegações e dos descobrimentos geográficos feito pelos portugueses. Propôs que a literatura originária dos ciclos da navegações fosse reconhecida pelos portugueses e brasileiros, porque tais investigações referiam-se à fontes de onde saiu, indelevelmente, selada a sociedade brasileira e também os escritos de eruditos e especialistas que levaram a cabo as investigações histónicas referentes aos ciclos das navegações. Com esses materiais positivos, com essas alegações de fatos seguros é que Portugal e Espanha se defendem do hipercriticismo, que é uma eiva derrotista do espírito nacional, e daquela lenda negra, que principiou no século XVI com o protestantismo e se adensou nos séculos seguintes $^{53}$. Fidelino de Figueiredo também reconheceu que a literatura brasileira em Portugal não cresceu ou não se popularizou visto falar de uma natureza e de um teor de vida que chocava pelo exotismo, enquan- 
to os leitores comuns procuravam prazer fácil de identidade e não caminhavam ao arrepio da sensibilidade ${ }^{54}$.

Já no século XIX, os intelectuais brasileiros enveredavam pela discussão da possibilidade de uma literatura genuinamente brasileira. As idéias nacionalistas brasileiras veiculadas pela literatura ou pela crítica literária incorporavam um pensamento de características etnocêntricas, não significando isto uma adesão total às idéias européias. $\mathrm{O}$ naturalismo de Zola ou a teoria climática de Montesquieu, Buffon e Buckle eram adaptadas e reelaboradas pelos intelectuais brasileiros. Neste trabalho, os intelectuais brasileiros afastaram-se profundamente das relaçõ es com Portugal ao ponto de J. Lúcio de Azevedo, na revista História, estar preocupado em verificar se "realmente existe no Brasil a idéia de que este país seja propriamente uma colônia mental de Portugal". Fez então uso de uma fala de Joaquim Nabuco na Academia Brasileira de Letras em que este colocava: "Portugal tem muito pouco de primeira mão que lhe queiramos tomar, uns e outros nos fornecemos de idéias, de erudição e pontos de vista nos fabricantes de Paris, de Londres e Berlim" ${ }^{\prime 55}$. Não se referiu à idéia básica do autor no que concerne à relação Brasil/Portugal em termos de literatura, pois, Joaquim Nabuco afirmou que:

"Julgo, porém, outra utopia igual pensarmos que nos havemos de desenvolver literariamente no mesmo sentido que Portugal, ou conjuntamente com ele, em tudo o que não depende do gênio da língua. $O$ fato é que, falando a mesma língua, Portugal e o Brasil têm de futuro destinos literários tão profundamente divididos como são os seus destinos nacionais. Querer a unidade em tais condições seria um esforço perdido ${ }^{n 56}$.

\section{NOTAS}

${ }^{1}$ No pós-doutoramento (Bolsa CAPES) tive a satisfação de ter como orientador o Prof. Dr. Luis Reis Torgal, professor catedrático da Universidade de Coimbra.

${ }^{2}$ Amado Mendes analisa a revista destacando que foi dirigida por Fidelino de Figueiredo. Participava de um movimento mais vasto, contrário à História Metódica, a qual deram também significativo contributo a Revue de Synthese Historique criada em França, por Henri Berr, em 1900, a escola sociológica durkheimiana, a que a história esteve bastante ligada, e a própria geografia, Vidal de La Blache e Lucien Febvre. (TORGAL, Luis Reis et al. História da História em Portugal . Lisboa, Temas e Debates, 1998, p. 242).

\footnotetext{
${ }^{3}$ Segundo Luís Reis Torgal "a Sociedade Nacional de História Portuguesa tinha como modelo a Sociedade Histórica Alemã, fundada pelo barão de Stein, que era igualmente defensora da política nacionalista germânica, surgida como reação às invasões francesas, e a Sociedade Histórica da Romênia, criada no contexto de um movimento de nacionalismo e de progresso".(Idem, p. 258).
} 
${ }^{4}$ A Revista Águia, publicada na cidade do Porto iniciou sua circulação em 1910/1932. Órgão do movimento saudosista, teve a colaboração de Teixeira Pascoaes, Manuel Laranjeira, Jaime Cortesão, Raul Proença, Veiga Simões, Mário Beirão, António Correia de Oliveira, Afonso Duarte, Afonso Lopes Vieira, António Sergio, Fernando Pessoa, Leonardo Coimbra, Unamuno, Raul Brandão, entre outros. (ROCHA, Clara. Revistas literárias do século XX em Portugal. Lisboa, Casa da Moeda, 1985, p. 637).

${ }^{5}$ A Nação Portuguesa: Dirigida sucessivamente por Alberto Monsaraz, António Sardinha e Manuel Múrias. Colaboraram na revista Manuel Múrias, Rolão Preto, João Ameal, António Sardinha, Castelo Branco Chaves além de outros. Veio para "reatar a Tradição". Coloca-se como sendo órgão do integralismo português. Posiciona-se contrária aos princípios da Revolução Francesa: liberté, egalité e fraternité.(Idem p. 640).

${ }^{6}$ A Revista Lusitânia entrou em circulação em 1924. Teve como diretora Carolina Michaëlis de Vasconcelos. Colaboradores: Afonso Lopes Vieira, Agostinho de Campos, António Sardinha, Antóno Sergio, Carlos Malheiro Dias, José Leite de Vasconcelos entre outros. Surgiu como um órgão da cultura portuguesa a serviço da "Reconstrução Nacional". (Idem, p. 643).

${ }^{7}$ A Revista Seara Nova começou a circular em 1921/1979. Faziam parte da direção da revista: Aquilino Ribeiro, Augusto Casimiro, Jaime Cortesão, Câmara Reys, Raul Brandão, Raul Proença, António Sérgio, Sarmento Pimental, rogério fernandes, Augusto Abelaria teve como colaboradores: Augusto Casimiro, Afonso Duarte, Américo Durão, Jaime Cortesão, Florbela, Gualdino Gomes, Carlos Queiroz, António Patrício, António de Sousa, Armindo Rodrigues, Vitorino Nemésio, Raul Brandão, Miguel Torga, Natália Correa entre outros.(Idem, p. 648).

$94 \quad{ }^{8}$ HOBSBAWM, Eric. A questão do nacionalismo: nações e nacionalismo desde 1780. Lisboa, Terramar, 1998, p. 31.

${ }^{9}$ FIGUEIREDO, Fidelino. "Um século de relações luso-brasileiras”. In Revista de História. Lisboa, nㅇs 53 a 56, 1925, p. 161.

${ }^{10}$ ALMEIDA, Renato. "Passadismo e imitação". Apud Revista de História. Lisboa, nos 53 a 56, 1925, p.162.

11 "Pelo termo de constituição estética deve-se entender a partilha do sensível que dá forma à comunidade. Partilha significa duas coisas: a participação em um conjunto comum e, inversamente, a separação, a distribuição dos quinhões. Uma partilha do sensível é, portanto, o modo como se determina no sensível a relação entre um conjunto comum partilhado e a divisão de partes exclusivas". (RANCIÈRE, Jacques. Políticas da Escrita. Trad. Raquel Ramalhete, Rio de Janeiro, Editora/34, 1995, p.07.)

${ }^{12}$ BOURDIEU, Pierre. Meditações Pascalinas . Oeiras, Celta Editora, 1998, p. 165.

${ }^{13}$ BRUNO, Sampaio. Brasil Mental . Porto, Lello Editores, 1998, p 39.

${ }^{14}$ HOBSBAWN, Eric, op. cit., pp. 85-86.

${ }^{15}$ SEVCENKO, N. A literatura como missão: tensões sociais e criação cultural na Primeira República. São Paulo, Brasiliense, 1989, p. 85.

${ }^{16}$ Ver RAMOS, M.B. e SERPA, E. C. A "Hermenêutica do Vazio: a viagem do governador ao oeste de Santa Catarina”. In Revista Projeto. São Paulo, no 18, 1999.

${ }^{17}$ MÚRIAS, Manuel. "A língua portuguesa no Brasil”. In Nação Portuguesa. vol. 08, 1928, p. 503. 
${ }^{18}$ ALMEIDA, Renato. "Passadismo e imitação". Apud Revista de História. Lisboa, noㅗ 53 a 56, 1925, p.162.

${ }^{19}$ MÚRIAS, M. op. cit, pp. 503-504.

${ }^{20}$ Jornal do Brasil. Apud Revista Águia. vol. XVII, 1919, p. 184.

${ }^{21}$ FOUCAULT, Michel. As palavras e as coisas: uma arqueologia das ciências humanas . Lisboa, Edições 70, 1989, p. 332.

${ }^{22}$ MENDONÇA, Renato. O Português do Brasil: origens, evolução, tendências. Rio de Janeiro, Civilização Brasileira, 1936, p. 81.

${ }^{23}$ FOUCAULT, M. op. cit, p. 337.

${ }^{24}$ BOURDIEU, Pierre. op., cit. p. 154.

${ }^{25}$ FOUCAULT, M. op. cit, p. 339.

${ }^{26}$ BOURDIEU, Pierre. op. cit., p. 161.

${ }^{27}$ CARTA do Brasil. Revista Águia. vol.18, 1920, p. 157.

${ }^{28}$ CARTA do Brasil. Revista Águia. vol. 19, 1921, p.72.

${ }^{29}$ OLIVEIRA, op. cit., p.43.

${ }^{30}$ BRUNO, S. op. cit, p. 86.

${ }^{31}$ O RLANDI, E. P. Terra à Vista. Discurso do confronto: velho e novo mundo. São Paulo, Cortez Editora, 1990, p.76.

${ }^{32}$ JÚNIOR, Araripe. "Lucros e perdas". In Coleção de Textos de Língua Portuguesa Moder na. Obra Crítica de Araripe Júnior . vol..I. Rio de Janeiro, Ministério da Educação e Cultura, 1958 p.351.

${ }^{33}$ Idem, p.351.

${ }^{34}$ a) A proposta do acordo mental para o crítico literário é natural. O sentimento é profundamente cosmopolita; mas nem é português, nem vem com o verdadeiro rótulo. Camilo Castelo Branco procede com mais lógica. "No fundo, não vê nisso senão uma recolonização psíquica; o que é um notável erro, senão uma imperdoável pretensão; b) como influência mental, a lição portuguesa é perturbadora da nossa evolução natural. O Brasil é uma amálgama. Querer guardar puras os caracteres dessa civilização, tão puros como imaginou Comte, é ir contra as leis da Sociologia, no que se refere à fusão das raças. O Comtismo é europeu e serve para todas as naçõ es decrépitas, incapazes de se renovarem por si mesmas. Doutrina talhada para o consolo e sossêgo das nações que na Europa atingiram o estágio concreto. $\mathrm{O}$ americano repele pela sua natureza arrojada, expansiva e aberta os pessismos de Comte na filosofia e de Zolá, na literatura; c)a tradição portuguesa não nos deve interessar tanto como aos que dela vivem unicamente. Preocupa-se com o passado quem não tem futuro...Os moço s revolvem as cinzas de onde sairão os elementos necessários à coordenação do presente.. O que nos adiantaria compartilharmos dessa preocupação constante das antigas navegações? mergulhar-nos no subjetivismo atroz, que faz padecer os moços a quem me refiro? Nada. Esta festa erguendo o orgulho colonial, amesquinhou o espírito nacional; d) no coice desta procissão, ostenta-se a questão econômica...refiro-me à diferenciação da colônia portuguesa, rica e numerosa e o brasileiro se sente cada vez mais distanciado, menos português. Solução. Abater uma e obrigá-la a absorver-se na outra, subordinando-a a uma nova coordenação de moléculas. Venha a grande naturalização; e que 
toda essa gente, que por aí anda a olhar-nos, assuma, o país, a responsabilidade individual e coletiva. Não se pode mais educar canários no reino para virem cantar no império."

${ }^{35}$ JUNIOR, Araripe. op. cit., pp. 277-278.

${ }^{36}$ BRAGA, Theóphilo. "Lucros e perdas. Cronica mensal dos acontecimentos, por Sylvio Romero e Arraripe Júnior, 1883". In Revista Estudos Livres. Lisboa, Nova Livraria Internacional, 1883-1884, pp. 334-335.

${ }^{37}$ CARTA do Brasil. Revista Àguia. Vols. 17-18, 1920, p. 162.

${ }^{38}$ DIAS, Carlos Malheiro. Conferência Rumo à Terra. "O problema da colonização portuguesa no Brasil". Revista Águia. vol. 18, jul./dez., 1920, p. 37.

${ }^{39}$ Idem, p. 37.

${ }^{40}$ GARRETT, João Baptista Leitão de Almeida. “Bosquejo da História da Poesia e língua Portuguesa”. In Obras de Almeida Garrett. Porto, Lello \& Irmãos - Editores, 1966, p. 503.

${ }^{41}$ Idem, p. 504.

${ }^{42}$ Parágrafo completo: "Inimigos do monopólio literário, não podemos resistir à tentação de repartir com o público tantas poesias inéditas ou raras, por antiga ou por extraviadas, que as investigações a que nos temos votado sobre a história da América nos haviam deparado”. VARNHAGEN, Francisco Adolfo de. Prólogo. In Florilégio da Poesia Brasileira . Rio de Janeiro, Academia Brasileira de Letras, 1946, tomo I, p. 01.

${ }^{43}$ Idem, pp. 05-06.

${ }^{44}$ ASSIS, Machado. "Notícia da atual literatura brasileira - instinto de nacionalidade". In Críti ca \& Variedades/Machado de Assis. São Paulo, Globo, 1997, pp. 19 e 21.

${ }^{45}$ VARNHAGEN, Francisco Adolfo de. História Geral do Brasil . São Paulo, Melhoramentos, 1956, vol. 04, p. 279.

${ }^{46}$ Sobre esta polêmica ver: ZILBERMAN, Regina. Almeida Garrett e a formação da cons ciência nacional . inédito, 1999.

${ }^{47}$ Sobre esta questão ver ANDERSON, Benedict. Nação e Consciência Nacional. São Paulo, Ática, 1989.

${ }^{48}$ CASTELO BRANCO, Camilo. Cancioneiro Alegre de Poetas Portugueses e Brasileiros. In ALMEIDA, Justino Mendes de. Obras Completas de Camilo Castelo Branco. Porto, Lello \& Irmãos - Editores, 1989, p 929.

${ }^{49}$ Idem, p. 1015.

${ }^{50}$ CASTELO BRANCO, Camilo. Os Críticos do Cancioneiro Alegre. In ALMEIDA, Justino Mendes de. Obras completas de Camilo Castelo Branco. Porto, Lello \& Irmãos - Editores, 1989, pp. 1391 e 1390.

${ }^{51}$ FRANÇA, Carlos. "Os portugueses no século XVI e a Histónia Natural do Brasil”. In Revista de História. noํ․ 57 a 60, 1926, p. 45.

${ }^{52}$ FRANÇA, Carlos. "Etnografia Brasílica segundo os escritores portugueses do século XVI" In Revista de História. nํs. 57 a 60, 1926, p. 215.

${ }^{53}$ FIGUEIRED O, Fidelino. "Do aspecto científico da colonização portuguesa da América". In Revista de História. nํㅗ. 53 a 56, 1925, p.197. 
${ }^{54}$ FIGUEIREDO, Fidelino. "Um século de relações luso-brasileiras”. In Revista de História. nํㅗ. 53 a 56, 1925, p. 161.

${ }^{55}$ AZEVEDO , J. Lúcio de. “América Latina e América Inglesa”. In Revista de História, № 11, jul./set., 1914.

${ }^{56}$ NABUCO, Joaquim. "Academia Brasileira de Letras". In Escritos e discursos literários. São Paulo/Rio de Janeiro, Cia Editora Nacional/Civilização Brasileira, 1939, p. 201. 